\title{
ANALISIS TEKNIK PENERJEMAHAN TINDAK TUTUR KOMISIF DALAM NOVEL ECLIPSE
}

\author{
Erika Agustina $^{1}$, Helda Jolanda ${ }^{2}$ \\ Program Studi Pendidikan Bahasa Inggris \\ Universitas Indraprasta PGRI \\ 1erika.agt@gmail.com,2jolandapentury69@gmail.com
}

\begin{abstract}
Abstrak
Penelitian ini adalah studi penerjemahan yang bertujuan untuk: (1) menganalisis jenis-jenis tindak tutur komisif dalam novel Eclipse dan terjemahannya; (2) menganalisis teknik penerjemahan yang digunakan oleh penerjemah dalam menerjemahkan setiap tindak tutur komisif dalam novel Eclipse; dan (3) mendeskripsikan efek teknik tindakan pidato komisif dalam novel Eclipse dalam hal akurasi dan penerimaan. Penelitian ini merupakan penelitian kualitatif deskriptif dengan fokus pada satu kasus. Data dalam penelitian ini adalah tindak tutur komisif dalam novel Eclipse yang diterjemahkan oleh Monica Dwi Chresnayani. Ada 122 tindak tutur komisif yang diambil datanya. Dalam penelitian ini, data juga kuesioner yang dikumpulkan dari 3 penilai yang memberikan tarif untuk keakuratan dan penerimaan dari produk terjemahan. Hasilnya adalah sebagai berikut: (1) ada 5 jenis tindak tutur komisif, seperti janji $52 \%$, mengancam $17 \%$, sukarela $13 \%$, melakukan $11 \%$, dan bersumpah $7 \%$; (2) dalam menganalisis teknik penerjemahan menggunakan teori Newmark, ditemukan 4 teknik penerjemahan. Mereka adalah terjemahan semantik $34 \%$, terjemahan literal $38 \%$, terjemahan komunikatif $17 \%$ dan terjemahan bebas $17 \%$. Oleh karena itu, penggunaan teknik penerjemahan memiliki dampak yang baik yang menghasilkan terjemahan yang akurat dan dapat diterima.
\end{abstract}

Kata kunci: pragmatik, tindak tutur komisif, terjemahan

\begin{abstract}
This research is the study of translation that aims to: (1) analyzing the types of commisive speech acts in Eclipse novel and its translation; (2) analyzing the translation techniques used by translator in translating every commisive speech acts in Eclipse novel; and (3) describe the effects of techniques of commisive speech acts in Eclipse novel in terms of accuracy and acceptability. This research is descriptive qualitative focuses on a single case. The data in this research are commisive speech acts in Eclipse novel translated by Monica Dwi Chresnayani. There were 122 commisive speech acts taken the data. In this study, the data were also questionnaires collected from 3 raters who gave rates to the accuracy and acceptability of the translation product. The results are as follows: (1) there were 5 kinds of commisive speech acts, such as promise $52 \%$, threaten $17 \%$, volunteering $13 \%$, undertake $11 \%$, and vowing 7\%; (2) in analyzing the translation techniques used Newmark theory, there were found 4 translation techniques. They are semantic translation $34 \%$, literal translation $38 \%$, communicative translation $17 \%$ and free translation 17\%. Hence, the use of translation techniques had a good impact that was producing accurate and acceptable translation.
\end{abstract}

Key words: pragmatics, commisive speech acts, translation

\section{PENDAHULUAN}

Teori terjemahan merupakan satu cabang linguistik yang menguraikan aspek-aspek bahasa, kebudayaan, dan komunikasi yang berperan dalam amalan terjemahan. Kata 'terjemahan' dapat diartikan sebagai proses mengukapkan kembali pesan yang terkandung dalam bahasa sumber (BSu) ke dalam bahasa sasaran (BSa). Dengan 
kata lain, menerjemahkan berarti menghasilkan kembali kesepadanan baik dalam makna dan juga gaya bahasa dalam bahasa sasaran.

Menerjemahkan merupakan suatu kegiatan yang harus memperhatikan tidak hanya perbedaan bahasa, tetapi juga perbedaan budaya yang melatari bahasa yang terlibat dalam penerjemahan. Untuk dapat menerjemahkan dengan hasil yang baik, penerjemah harus menguasai tidak hanya kedua bahasa yang terlibat, tetapi juga kebudayaan yang melatari kedua bahasa itu.

Terjemahan dapat dibedakan menurut bentuk teksnya, antara lain teks sastra, teks teknis, teks keagamaan. Dalam penelitian ini penulis mencoba membahas teks sastra dalam novel terjemahan "Eclipse" karya Stepahie Mayer. Novel menjadi bagian dari karya sastra dan sebagai hasil pekerjaan kreasi manusia karya sastra yang berupa novel tidak akan pernah lepas dari bahasa yang merupakan media utama dalam karya sastra. Sastra dan manusia sangat erat kaitannya karena keberadaan sastra sering bermula dari pemasalahan serta persoalan dengan daya imajinasi yang tinggi. Pengarang menuangkan masalah yang ada di sekitarnya menjadi karya sastra.

Sebagai media komunikasi, bahasa sangat erat kaitannya dengan kultur dan kebiasaan penutur dalam melakukan interaksi sosial. Bahasa telah menjadi perekat komunikasi yang menyejarah dalam peradaban umat manusia dari generasi ke generasi. Bahkan, dalam perkembangannya bahasa telah menjadi sebuah ikon dan simbol status sosial penuturnya. Tidak berlebihan apabila penutur alias pengguna bahasa berusaha mengekspresikan dan mengaktualisasikan jati diri melalui bahasa yang sesuai dengan situasi kultural dan gaya tutur personalnya.

Dalam berbahasa terdapat sebuah hal yang disebut dengan tindak tutur. Tindak tutur adalah salah satu kegiatan fungsional manusia sebagai makhluk berbahasa. Sifatnya yang fungsional tersebut menyebabkan setiap manusia selalu berupaya untuk mampu melakukan tindak tutur dengan sebaikbaiknya, baik melalui pemerolehan (acquisition) maupun pembelajaran (learning). Tindak tutur merupakan analisis pragmatik, yaitu cabang ilmu bahasa yang mengkaji bahasa dari aspek pemakaian aktualnya.

Salah satu aspek yang menarik untuk dijadikan bahan kajian dalam penerjemahan novel adalah bentukbentuk tindak tutur atau yang dikenal sebagai speech act. Tindak tutur (speech act) merupakan salah satu bagian ilmu Pragmatik yang menarik untuk dikaji keterkaitannya dengan penerjemahan novel. Tindak tutur membahas tentang makna tuturan atau intention (maksud) yang terkandung dalam suatu tuturan.

$\begin{array}{cccc}\text { Salah } & \text { satu kategori tindak } \\ \text { tutur yang akan dipilih } & \text { dalam }\end{array}$ penelitian ini adalah komisif. Tindak tutur komisif adalah tindak tutur yang mengikat penuturnya untuk melaksanakan segala hal yang disebutkan dalam ujarannya, misalnya bersumpah, berjanji, mengancam, menyatakan kesanggupan, berkaul. Contoh tindak tutur komisif kesanggupan adalah "Saya sanggup melaksanakan amanah ini dengan baik". Tuturan itu mengikat penuturnya untuk melaksanakan amanah dengan sebaikbaiknya. Hal ini membawa konsekuensi bagi dirinya untuk memenuhi apa yang telah dituturkannya. Contoh tuturan yang lain adalah "Besok saya akan datang ke pameran lukisan Anda", "Jika 
sore nanti hujan, aku tidak jadi berangkat ke Solo".

Dalam penerjemahan novel, tentu ada pengalihan pesan dari Bahasa Sumber (BSu) ke Bahasa Sasaran (BSa). Terkait dengan tindak tutur tentu saja pesan yang dialihkan ke dalam BSa haruslah sama dengan pesan yang terkandung dalam $\mathrm{BSu}$ yaitu intention 'maksud' dari pembicara. Artinya, dalam menerjemahkan tindak tutur tertentu, intention 'maksud' yang terkandung dalam BSu tidak boleh berubah jenis maupun fungsinya setelah menjadi BSa. Sehingga, bukan hanya bentuk tindak tuturnya yang dialihkan tapi juga makna yang terkandung dari tindak tutur tersebut. Seorang penerjemah harus bisa memperhatikan hal tersebut sehingga ia bisa menjembatani perbedaan antara kedua bahasa dengan menghasilkan terjemahan yang berkualitas tanpa mengubah pesan yang terkandung dalam BSu.

Sehubungan dengan makna yang terkandung dalam terjemahan tindak tutur, penggunaan teknik penerjemahan sangatlah penting. Teknik penerjemahan adalah suatu cara yang digunakan oleh penerjemah untuk dapat menghasilkan terjemahan yang sesuai dengan bahasa sumbernya (Molina dan Albir, 2002: 509).

Terkait dengan hasil terjemahan yang berkualitas atau tidak, ada suatu hal yang perlu diperhatikan yaitu tentang penilaian mutu/ kualitas terjemahan. Dalam penilaian kualitas terjemahan ada beberapa aspek yang perlu ditinjau, yaitu aspek keakuratan, keberterimaan, dan keterbacaan. Ketiga aspek ini sangat penting dalam menentukan apakah suatu produk terjemahan dapat menjalankan dengan baik fungsinya sebagai alat komunikasi. Aspek keakuratan berhubungan dengan akurat atau tidaknya pengalihan pesan teks dalam bahasa sumber ke dalam bahasa sasaran. Keberterimaan berhubungan dengan masalah terjemahan tersebut sesuai atau tidak dengan kaidah dan budaya yang berlaku dalam bahasa sasaran. Sedangkan aspek keterbacaaan menyangkut masalah terjemahan tersebut dapat dipahami dengan mudah atau tidak oleh pembaca sasaran.

\section{METODE PENELITIAN}

Dalam penelitian ini digunakan pendekatan kualitatif dengan metode analisis isi (content analysis) dalam novel Eclipse baik yang berbahasa Inggris sebagai $\mathrm{BSu}$ dan novel terjemahannya sebagai BSa. Data diambil dari dialog para tokoh dalam berinteraksi satu sama lain di dalam novel, sehingga datanya akan berbentuk kata, frasa, klausa, atau kalimat. Disebut penelitian deskriptif karena penelitian ini tidak sebatas pada pengumpulan dan penyusunan data saja tetapi juga meliputi mulai dari mengumpulkan, mengelompokkan, menganalisa, dan menginterpretasikan data penelitian (Winarno, 1995).

Pendekatan yang digunakan dalam penelitian ini adalah pendekatan penerjemahan. Teori yang akan digunakan adalah tentang teknik dan kualitas terjemahan. Teori pragmatik mengenai tindak tutur komisif sebagai salah satu perspektif linguistik juga merupakan komponen penting dalam penelitian ini. Teori pragmatic tindak tutur komisif akan digunakan untuk menentukan karakteristik data. Oleh karena data berupa tuturan komisif, maka satuan lingual data berupa kata, frasa, dan kalimat. Satuan lingual inilah yang akan akan digunakan sebagai dasar penentuan teknik terjemahan yang digunakan penerjemah. Selanjutnya, penerapan teknik terjemahan masing- 
masing data akan dianalisis kaitannya dengan kualitas terjemahan yang meliputi keakuratan dan keberterimaan.

\section{HASIL DAN PEMBAHASAN}

\section{Tindak Tutur Komisif}

Pada bagian ini, data penelitian yang berupa tindak tutur komisif dalam novel Eclipse akan dikategorikan berdasarkan bentuk dan fungsi komisif pada satuan lingual kata, frasa, klausa, atau kalimat yang meliputi: (1) 'berjanji' (promise) dengan jumlah data sebanyak 63 ujaran (52\%); (2) disusul bentuk ujaran 'mengancam' (threaten) sebanyak 21 (18\%); (3) 'menyatakan kesanggupan' (volunteering) ada 16 (13\%), (4) bentuk ujaran 'berniat' (undertake) ditemukan berjumlah 13 (11\%), dan (5) bentuk ujaran yang terkecil 'bersumpah' (vowing) berjumlah 9 (7\%). Semua data diperoleh dari novel Eclipse yang terdiri dari 27 bab, baik novel asli berbahasa Inggris sebagai referensi BSu dan novel terjemahannya sebagai referensi.

\section{a. Berjanji (promise)}

Berjanji dapat diartikan sebagai kesanggupan seseorang untuk menepati apa yang telah dikatakan atau telah disetujui. Tindak tutur komisif berjanji adalah suatu tindakan bertutur yang dilakukan oleh penutur dengan menyatakan janji akan melakukan suatu pekerjaan yang diminta orang lain. Janji itu dilakukan dalam kondisi tulus (sungguh-sungguh). Orang yang akan melakukan tindakan itu ialah orang yang mempunyai kesanggupan atas pekerjaan/tindakan. Bentuk tindak tutur komisif yang paling dominan dalam penelitian ini adalah 'berjanji' (promise) sebanyak 63 data (52\%). Dominasi tindak tutur tersebut sesuai dengan cerita Eclipse, cerita tentang cinta segitiga antara Bella, Edward, Jacob. Hampir sepanjang cerita isinya adalah dialog antara Bella dan Edward, Bella dan Jacob, atau pun Edward dan Jacob, dan tidak terhindarkan ketiganya terlibat dalam satu ketegangan. Ketika Bella sedang bersama Edward, mereka membicarakan Jacob. Ketika Bella sedang bersama Jacob, mereka membicarakan Edward. Sebagai kekasih Bella, Edward tidak bisa berhenti mengkhawatirkan Bella ketika sedang bersama Jacob karena baginya si manusia serigala itu bukanlah "makhluk" yang stabil secara emosional. Sebaliknya, Jacob juga selalu khawatir kalau-kalau Edward sang vampir tiba-tiba mengubah Bella menjadi vampir juga. Dalam berbagai kesempatan berdua, Jacob terus saja mempengaruhi Bella agar memilih dirinya ketimbang Edward. Jacob meyakinkan bahwa dirinya lebih baik ketimbang Edward. "Until your heart stops beating, Bella," he said. "I'll be here - fighting. Don't forget that you have options." (15:330) adalah salah satu tuturan 'janji' yang dikatakan Jacob kepada Bella untuk meyakinkan Bella bahwa dia lebih baik daripada Edward. Demikain halnya ketika Edward menyatakan janjinya kepada 
Bella untuk tidak pergi jauh, "I won't be far away You'll be safe" (10:214). Janji itu dia sampaikan ketika Edward akan pergi dan Bella mencegahnya karena khawatir.

Tuturan 'janji' dalam penelitian ini tidak hanya berfokus pada tuturan yang disampaikan ketiga tokoh utama tersebut, namun juga tokohtokoh cerita lainnya, misalnya janji Charlie -sang ayah kepada Bella, janji Alice kepada Bella dan Edward dan banyak tuturan janji lainnya.

Contoh lainnya:

BSu: There's no hurry. I won't let anyone hurt you. You can take all the time you need." (1:25)

BSa: "Tidak perlu buru-buru. Aku takkan membiarkan siapa pun menyakitimu. Ambil waktu sebanyak yang kau butuhkan." $(1: 38)$

Dialog tersebut terjadi ketika Edward dan Bella yang membicarakan tentang kebimbangan Bella dalam melanjutkan studinya setelah dia lulus dan akan melanjutkan ke perguruan tinggi. Bella berencana melanjutkan kuliah di Alaska bukan karena biayanya yang lebih murah -sebagaimana alasan yang dia kemukakan kepada ayahnya, Charlie- akan tetapi jaraknya yang sangat jauh dan itu merupakan saran Edward. Dia menyarankan Bella untuk kuliah di Darthmouth yang mana disana ada kuliah malam yang cukup lengkap untuknya. Banyak hewan liarnya. Edward yang seorang vampire tidak memungkinkan kuliah musim gugur dan tidak mungkin berdekatan dengan manusia.

Ujaran tersebut termasuk bentuk tindak tutur komisif 'janji'. Janji yang disampaikan Edward kepada Bella. Bella yang ingin segera memasuki dunia vampire disarankan untuk tidak terlalu buru-buru karena butuh persiapan matang, dan untuk hal tersebut Edward yang sangat mencintai Bella berjanji akan menjaganya dari werewofl atau vampire jahat jika ada yang menganggunya kelak.

\section{b. Mengancam (threaten)}

Peringkat kedua bentuk tindak tutur komisif adalah 'mengancam' (threaten) sebanyak 21 data (17\%). Mengancam adalah menyatakan maksud (niat, rencana) untuk melakukan sesuatu yang merugikan, menyulitkan, menyusahkan atau mencelakakan pihak lain. Dalam pragmatik, tindak tutur komisif ancaman adalah tindak tutur yang dilakukan oleh penutur dengan maksud agar mitra tutur melakukan tindakan yang disebutkan dalam tuturan yang berisi mengancam. Tuturan ancaman adalah tuturan yang dilakukan oleh seseorang dengan maksud untuk menyuruh kepada orang lain secara paksa, biasanya berkonotasi kasar.

Cerita dalam novel ini termasuk romantis horor, antara cinta dan pertarungan vampire dan warewolf. Tentang sejumlah peristiwa pembunuhan misterius 
di Seattle, oleh sejumlah kelompok vampire karena ingin membalas dendam atas kematian salah satu anggota kelompoknya. $\mathrm{Di}$ tengah peristiwa kematian misterius yang berkepanjangan, dan mencekam itulah, Bella terjepit di situasi yang tidak menguntungkan itu. Karena pada saat bersamaan, Edward, kekasih yang vampire tapi berbudi, karena tidak mengkonsumsi darah manusia kecuali hewan, harus berhadapan dengan Jacob, manusia warewolf. Jacob adalah teman sekaligus penggoda hati Bella. Di tengah keputusan yang serba sulit, antara memilih kekasih hati atau kawan baik terpilih, Bella hanya mempunyai satu kesempatan; menyelamatkan cintanya, atau mati.

\section{Tuturan 'mengancam'} yang ditemukan dalam penelitian ini tidak hanya tuturan ancaman yang bersifat mengintimidasi lawan tuturnya tapi juga ancaman yang bersifat direktif dimana lawan tuturnya diminta untuk melakukan sesuatu untuk ingin mendapatkan sesuatu. Misalnya, "If you can't be nice, I won't come back at all." (5:150), adalah bentuk 'ancaman' Bella kepada Jacob agar bersikap lebih baik jika dia menginginkan Bella datang kembali. Dalam hal ini menutur memberikan 'ancaman' dalam bentuk perintah atau saran kepada lawan tutur untuk melakukan apa yang dia tuturkan, namun apabila lawan tutur tidak melakukan apa yang dia 'ancamkan' maka penutur akan melakukan aksinya.

Contoh lainnya:

BSu: "Then I suggest you to remove from school property at once, young man, before I call the police." (3:84)

BSa: "Kalau begitu, kusarankan kau segera angkat kaki dari halaman sekolah, anak muda, sebelum aku memanggil polisi." (3:102)

Tindak tutur komisif 'mengancam' dalam dialog tersebut terlihat dalam ujaran, "before I call the police" (sebelum aku memanggil polisi). Ancaman Mr. Greene -kepala sekolah Bella dan Edwardterhadap Jacob. Mr. Greene tibatiba menebus kerumunan penonton yang melihat perseteruan antara Edward dan Jacob di halaman sekolah mereka memperingatkan Jacob untuk tidak masuk lagi ke sekolah mereka tanpa izin. Jacob bersekolah di sekolah Quileute.

$$
\text { Jacob mendatangi }
$$

sekolah Bella bertujuan untuk bertemu dengan Edward. Di tengah kerumunan kawan sekolahnya, Jacob datang dengan membawa amarah terhadap Edward yang mana kakak lelakinya telah melanggar batas wilayah pada Sabtu malam. Sesuatu telah terjadi pada malam itu tanpa sepengetahuan Bella karena Edward telah membawanya pergi menjauh pada saat itu. Bella hanya bisa menyimpulkan bahwa Victoria kembali mencari dirinya. Victoria takkan pernah menyerah sampai dirinya mati. Victoria mencari dirinya untuk 
membalas dendam terhadap Edward, ia menganggap Edward bertanggung jawab atas kematian kekasihnya, James. Ia tidak akan berhenti sampai berhasil merenggut kekasih Edward juga.

Tuturan yang disampaikan Mr. Greene menunjukkan bahwa dia tidak suka dengan kehadiran Jacob, dia meneliti Jacob dengan seksama, dan dia menyimpulkan bahwa Jacob adalah orang lain yang berbahaya. Berandalan. Oleh karenanya dia segera meminta Jacob untuk segera meninggalkan sekolah tersebut atau, jika tidak, dia akan memanggil polisi untuk mengamankan Jacob.

\section{c. Menyatakan Kesanggupan (volunteering)}

Tindak

'menyatakan

tutur kesanggupan' (volunteering) adalah bentuk komisif selanjutnya yang memiliki jumlah 16 data (13\%). Kesanggupan dalam hal ini adalah kemampuan dan kesediaan seseorang untuk berbuat atau tidak berbuat sesuatu. Misalnya dalam tuturan ini, "I'll help Jesper when he needs it. He wants to try some unequel grouping, teach them how to deal with multiple attackers." (19:429), adalah tuturan kesanggupan Edward untuk membantu Jesper melawan musuh mereka yang akan menyerang dalam waktu dekat. Dalam temuan data, tuturan bentuk ini sering dilakukan Edward kepada Bella. Namun didapati juga kesanggupan Bella untuk melakukan sesuatu, misal,
"I want to help. I have to do something," I insisted. (19:414).

Tuturan tersebut disampaikan Bella kepada Edward saat dia menceritakan rencana pertarungan bersama Jesper melawan para monster untuk menyelamatkan Bella

Contohnya:

BSu: "I'll help you," I volunteered. "If you don't mind my awful handwriting." (1:37)

BSa: "Aku bisa membantumu," aku menawarkan diri. "Kalau kau tidak keberatan dengan tulisan tanganku yang jelek." (1:51)

$$
\text { Ujaran }
$$

tersebut disampaikan Bella kepada Angela yang baru saja menceritakan bahwa surat pemberitahuan tentang kelulusannya telah dibantu penulisannya oleh ibunya dengan tulisan tangannya sendiri kepada sepupu ibunya yang banyak sekali. Angela mengatakan bahwa ia tidak bisa menunda-nundanya lagi, dan membayangkan ngeri rasanya apabila dia melakukan hal tersebut sendirian, tanpa bantuan ibunya. Ujaran yang ditawarkan Bella tersebut dapat dikategorikan sebagai bentuk tindak tutur komisif 'menyatakan kesanggupan', sekalipun kesanggupan yang ditawarkan Bella tersebut berbentuk guyonan untuk menanggapi cerita Angela. Dapat tergambar bahwa dalam situasi tersebut Bella dengan senang hati menawarkan jasanya untuk membantu Angela apabila diperlukan, yakni membantu Angela menuliskan surat pemberitahuan tentang 
kelulusannya sebagaimana yang telah dilakukan oleh ibunya kepada sepupu ibunya yang banyak itu

\section{d. Berniat (undertake)}

Bentuk tindak tutur selanjutnya adalah 'berniat' (undertake), total data yang ditemukan sebanyak 13 data atau $11 \%$. 'Berniat' dalam tindak tutur komisif adalah menyatakan suatu pekerjaan/tindakan bagi orang lain. 'Berniat' dalam temuan data disini tidak saja berniat untuk melakukan tindakan negatif yang merugikan pihak lain, tapi juga berniat untuk tindakan positif. Tidak hanya berniat yang ditujukan kepada orang lain tapi juga ditujukan untuk diri sendiri. Niat itu dilakukan dalam kondisi ketulusan dengan pelaku tindakan betul-betul penutur sendiri. Tindakan tersebut belum dilakukan, dan akan dilakukan pada masa mendatang. Misalnya saja pada tuturan ini: "I'll try to behave myself." (5:116). Tuturan tersebut diutarakan Jacob kepada Bella, niat Jacob untuk dirinya sendiri untuk bersikap lebih baik. Secara gramatikal, dalam BSu bentuk kalimat yang didalamnya terdapat modal will adalah future tense dimana subjek pelaku berniat atau berencana untuk melakukan suatu kegiatan. 'Berniat' dari data yang terkumpul dalam penelitian ini dikemukakan oleh merata hampir semua tokoh cerita.

Contoh lainnya:
BSu: "All the more reason to fight - fight harder now, while I can," he whispered. (15:330)

BSa: "Berarti semakin kuat alasanku untuk berjuangberjuang lebih keras lagi sekarang, mumpung aku masih bisa," bisiknya (15:362)

Jacob berharap Bella memilihnya daripada Edward, sebab apabila dia memilih Edward maka Bella akan memasuki dunia vampire dan itu sangat tidak diharapkan Jacob. Tuturan diatas dapat diartikan sebagai tindak tutur komisif 'berniat'. Niat Jacob untuk berusaha mempertahankan Bella agar tetap memilihnya, karena dia tahu bahwa saat ini Bella dalam kebimbangan, memilih dirinya atau Edward. Kalimat 'semakin kuat alasanku untuk berjuang-berjuang lebih keras' adalah niat Jacob untuk merebut hati Bella, bukan berjuang melawan vampire atau siapapun. Niat, suatu tindakkan yang belum dilakukan namun berkeinginan kuat untuk melakukannya.

\section{e. Bersumpah (vowing)}

Bersumpah adalah pernyataan tekad melakukan sesuatu untuk menguatkan kebenaran atau berani menderita sesuatu jika pernyataan tersebut tidak benar. Dalam tindak tutur komisif, bersumpah adalah tindak tutur untuk meyakinkan mitra tutur tentang apa yang dilakukan/dituturkan oleh penutur ialah benar seperti yang dikatakan. Tuturan bersumpah ini menggunakan penanda tuturan yang dapat meyakinkan lawan tutur, sering kali dengan 
menyebut saksi yang derajatnya lebih tinggi. Contohnya:

BSu: I'll never forgive myself for leaving you," he whispered.

"Not if I live a hundred thousands years." (1:33)

BSa: "Aku tidak akan pernah memaafkan diriku sendiri karena meninggalkanmu," bisiknya. "Tidak seandainya aku hidup sampai seratus ribu tahun sekalipun." (1:47)

Tuturan tersebut diungkapkan Edward kepada Bella. Situasi yang terjadi dalam dialog tersebut yakni ketika Bella meminta ijin Edward untuk dapat menemui Jacob. Saat ini Jacob menderita dan membutuhkan kehadirannya. Keluarga Jacob Black sudah seperti keluarga sendiri bagi Charlie, oleh karena itu ayahnya menyarankan Bella untuk menemui Jacob mengingat mereka berdua dulunya akrab sekali. Bella merasa berhutang budi terhadap Jacob yang telah menolongnya ketika Edward pergi untuk beberapa lama. Ia merasa betapa besar hutang budinya kepada Jacob Black, lebih dari hidupnya, dan mungkin kewarasnnya juga.

Tuturan Edward di atas termasuk bentuk tindak tutur komisif 'bersumpah' karena Edward bersumpah pada dirinya sendiri untuk tidak akan pernah pergi meninggalkan Bella lagi. Bila hal itu terjadi lagi, dia bersumpah tidak akan memaafkan dirinya sendiri walaupun untuk hidup sampai seratus ribu tahun sekalipun. Dia menyesalkan kepergiannya, sekalipun kepergiannya waktu itu dimaksudkan untuk menyelamatkan Bella, demi rasa tanggung jawabnya kepada Bella. Dia berpendapat, seandainya dia tidak pergi, maka Bella tidak akan merasa perlu mempertaruhkan hidupnya untuk menghibur Jacob.

\section{Teknik Penerjemahan Tindak Tutur Komisif}

Dalam penelitian ini, peneliti menggunakan teori yang dikemukakan oleh Newmark (1988:45) dimana dia menjabarkan delapan cara dalam teknik penerjemahan, yakni: Word-forword translation, Literal translation, Faithful translation, Semantic translation, Adaptation, Free translation, Idiomatic translation, dan Communicative translation. Setelah dikaji lebih dalam, teknik penerjemahan yang digunakan dalam novel Eclipse, menurut data penelitian, ditemukan empat teknik penerjemahan yang digunakan penerjemah dalam menerjemahan novel tersebut, yaiutu: penerjemahan semantik (semantic translation) sebanyak 43 data atau 34\%. Penerjemahan harfiah (literal translation) berjumlah 46 data atau $38 \%$. Penerjemahan komunikatif (communicative translation) menempati peringkat ketiga, setelah penerjemahan harfiah yakni sebanyak 21 data atau $17 \%$ dari 118 data yang ada. Adapun penerjemahan bebas (free translation) menduduki peringkat terakhir dalam penelitian ini, yakni sebanyak 12 data atau $10 \%$ dari total keseluruhan data kolektif yang ada. 

a. Penerjemahan Semantik
(Semantic Translation)

Dalam penerjemahan
harus
semantis remsur
mempertimbangkan unsur
estetika teks BSu dengan cara
mengkompromikan makna
selama masih dalam batas
kewajaran.
penerjemahan ini paling sering
digunakan oleh penerjemah
dalam menerjemahkan novel
Eclipse.

Contohnya:

$\mathrm{BSu}$ : "Please, for me. Please make a conscious effort to keep yourself safe. I'll do everything I can, but I would appreciate a little help." (1:33)

BSa: "Please, demi aku. Please, berusahalah agar kau tetap aman. Aku akan melakukan apa saja yang kubisa, tapi aku akan sangat senang kalau mendapat sedikit bantuan darimu. (1:48)

Frasa 'make a conscious effort to keep yourself safe' dan 'appreciate a little help' diterjemahkan menjadi 'berusahalah agar kau tetap aman' dan 'sangat senang kalau mendapat sedikit bantuan darimu'. Secara harfiah 'conscious' adalah adjektiva yang berarti 'sadar' sedangkan 'make' dan 'keep' adalah verba yang berarti 'membuat' dan 'menjaga', namun dalam penerjemahannya penerjemah menggunakan varian ganda/kuplet, dalam hal ini mereduksi kata 'conscious', 'make' dan 'keep'. Kemungkinan hal ini dilakukan adalah untuk menyepadankan kalimat BSu ke dalam BSa agar terkesan natural dan lebih mudah dipahami oleh pemakai bahasa sasaran.

\section{b. Penerjemahan Harfiah (Literal Translation)}

Dalam proses penerjemahan harfiah, penerjamah mencari konstruksi gramatikal $\mathrm{BSu}$ yang sepadan atau dekat dengan BSa. Penerjemahan ini mula-mula dilakukan seperti penerjemahan kata demi kata, tetapi penerjemah kemudian menyesuaikan susunan katakatanya sesuai dengan gramatikal Bsa.

$\mathrm{BSu}$ : "Don't worry about it." (5:129)

BSa : "Jangan mengkhawatirkan soal itu." (5:149)

Tuturan bentuk 'berjanji' $\mathrm{BSu}$ tersebut secara harfiah diterjemahkan ke dalam BSa, kesepadanannya dapat dipahami dengan baik. Tuturan "Don't worry about it." diterjemahkan menjadi "Jangan mengkhawatirkan soal itu." Secara gramatikal dan leksikal tidak terjadi pergeseran, semua diterjemahkan sesuai dengan konteks BSu-nya.

\section{c. Penerjemahan Komunikatif (Communicative Translation)}

Dalam penerjemahan komunikatif (communicative translation), penerjemah berupaya untuk menerjemahkan makna kontekstual dalam teks Bsu, baik aspek kebahasaan maupun aspek isinya, agar dapat diterima dan dimengerti oleh pembaca. Pada umumnya, 
penerjemah

sangat

memperhatikan keefektifan

bahasa terjemahan.

BSu: "I'll give you a pedicure and everything". (6:146)

BSa: "Aku akan memberimu layanan pedikur, lengkap dengan perawatan lainnya." (6:168)

Frasa 'a pedicure and everything' diterjemahkan menjadi 'layanan pedikur, lengkap dengan perawatan lainnya'. Kata yang dapat dilihat secara harfiah pada penerjemahan tersebut hanyalah 'pedicure' sementara 'everything' menjadi 'lengkap dengan perawatan lainnya'. Secara leksikal, kata 'everything' merupakan kata gabung yang dapat diartikan 'apa saja' sesuai dengan kalimat yang disertainya. Dapat diceritakan bahwa situasi dalam tuturan tersebut adalah ketika Bella, Alice dan kawan-kawannya sedang mempersiapkan pesta untuk malam harinya. Karena baru kali pertama Bella bergabung dalam pesta keluarga vampire maka Alice menjanjikan beberapa hal untuk persiapan pesta tersebut, termasuk 'pedicure' kepada Bella. Dalam hal ini, penerjemah menggunakan teknik transposisi penambahan, yakni everything' menjadi 'lengkap dengan perawatan lainnya'.

\section{d. Penerjemahan Bebas (Free \\ Translation) \\ Penerjemahan bebas (free \\ translation) merupakan \\ penerjemahan yang lebih}

mengutamakan isi dari pada bentuk teks BSu. Biasanya metode ini berbentuk parafrase yang lebih panjang daripada bentuk aslinya, dimaksudkan agar isi atau pesan lebih jelas diterima oleh pengguna $\mathrm{BSa}$. Contohnya:

BSu: "I'll make it up to you, you wash, I'll rinse and dry." (10:217)

BSa: "Aku akan 'menebus' dosa-dosaku, kau mencuci, aku yang membilas dan mengeringkan." (10:241)

Frase 'make it up to you' diterjemahkan menjadi 'menebus dosa-dosaku', sedangkan secara harfiah frase tersebut berarti 'berusaha menyenangkan seseorang'. Hal ini dilakukan penerjemah kemungkinan meyesuaikan dengan situasi cerita yang ada dalam novel tersebut. Dalam cerita tersebut, Bella yang sedang mencuci piring di dapur dikagetkan oleh seruan Jacob, membuat Bella melompat dan tertumpah air. Melihat hal tersebut Jacob segera meraih lap dan mengeringkannya. Oleh karena itu, masih menyesuaikan dengan situasi dalam cerita yang ada, maka pada kalimat 'I'll rinse and $d r y$ ' dipertahankan sesuai dengan kalimat aslinya menjadi 'aku yang membilas dan mengeringkan'. Jadi dapat dikatakan bahwa pada bagian ini teknik yang dipakai ada dua cara yakni bebas dan harfiah. 
3. Penilaian Kualitas Terjemahan

\begin{tabular}{|c|c|c|c|c|c|c|c|}
\hline \multirow[b]{2}{*}{$\begin{array}{c}\text { Bentuk Tindak } \\
\text { Tutur }\end{array}$} & \multirow[b]{2}{*}{ 蔦 } & \multicolumn{3}{|c|}{ Tingkat Keakuratan } & \multicolumn{3}{|c|}{$\begin{array}{c}\text { Tingkat } \\
\text { Keberterimaan }\end{array}$} \\
\hline & & 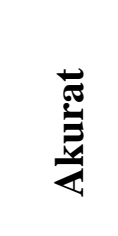 & 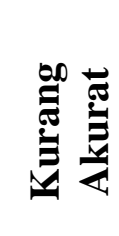 & 尝 & 离 & 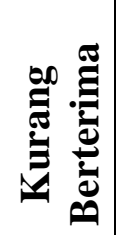 & 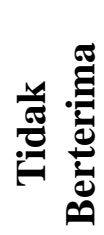 \\
\hline JANJI & $\begin{array}{c}63 \\
(51 \%)\end{array}$ & $\begin{array}{c}58 \\
(92 \%)\end{array}$ & $\begin{array}{c}4 \\
(6 \%)\end{array}$ & $\begin{array}{c}1 \\
(2 \%)\end{array}$ & $\begin{array}{c}59 \\
(94 \%)\end{array}$ & $\begin{array}{c}3 \\
(5 \%)\end{array}$ & $\begin{array}{c}1 \\
(2 \%)\end{array}$ \\
\hline ANCAMAN & $\begin{array}{c}21 \\
(17 \%)\end{array}$ & $\begin{array}{c}17 \\
(81 \%)\end{array}$ & $\begin{array}{c}4 \\
(19 \%)\end{array}$ & - & $\begin{array}{c}20 \\
(95 \%)\end{array}$ & $\begin{array}{c}1 \\
(5 \%)\end{array}$ & - \\
\hline KESANGGUPAN & $\begin{array}{c}16 \\
(13 \%)\end{array}$ & $\begin{array}{c}13 \\
(81 \%)\end{array}$ & $\begin{array}{c}3 \\
(19 \%)\end{array}$ & - & $\begin{array}{c}15 \\
(94 \%)\end{array}$ & $\begin{array}{c}1 \\
(6 \%)\end{array}$ & - \\
\hline BERNIAT & $\begin{array}{c}13 \\
(11 \%)\end{array}$ & $\begin{array}{c}11 \\
(85 \%)\end{array}$ & $\begin{array}{c}2 \\
(15 \%)\end{array}$ & - & $\begin{array}{c}13 \\
(100 \%)\end{array}$ & - & - \\
\hline SUMPAH & $9(7 \%)$ & $\begin{array}{c}8 \\
(89 \%)\end{array}$ & $\begin{array}{c}1 \\
(11 \%)\end{array}$ & - & $\begin{array}{c}9 \\
(100 \%)\end{array}$ & - & - \\
\hline Total & 122 & 107 & 14 & 1 & 116 & 5 & 1 \\
\hline
\end{tabular}

Dari 122 data analisis tentang terjemahan tindak tutur komisif dalam novel Eclipse, diperoleh sebanyak 107 data, atau $88 \%$ terjemahan tindak tutur komisif dalam novel Eclipse diterjemahkan secara akurat, sementara yang nampak kurang akurat tercatat sekitar 14 data atau $11 \%$. Sedangkan ketidakakuratan tercatat 1 data saja, atau $1 \%$. Dengan hasil temuan tersebut, maka terjemahan tindak tutur komisif merupakan terjemahan yang baik karena mempunyai nilai indikator keakuratan paling tinggi. Dari segi keberterimaan, data yang berterima ditemukan sebanyak 116 atau $95 \%$, 5 data atau $4 \%$ termasuk ke dalam kategori kurang berterima dan hanya 1 data atau $1 \%$ saja yang tidak berterima.

Teknik penerjemahan harfiah sering digunakan dikarenakan secara struktur gramatikal dan leksikal dari BSu ke BSa tidak perlu dilakukan pergeseran karena tanpa dilakukan pun makna keduanya sepadan, akurat dan dapat diterima dengan baik oleh pembaca BSa. Misalnya: (1) BSu: "Don't worry about it." (5:129), BSa: "Jangan mengkhawatirkan soal itu." (5:149); (2) BSu: “Okay, I won't do it again, promise." (5:129), BSa: "Oke, aku tidak akan melakukannya lagi janji." (5:149). Dari kedua contoh tersebut, penerjemah tidak melakukan 
pergeseran apapun karena kedua bahasa tersebut cukup sepadan. Pada contoh (2), kata 'okay' juga tidak diganti dengan kata lain sekalipun dalam BSa ada pengantinya, misalnya 'baiklah' yang mempunyai makna dan kedudukan yang sama. Dalam hal ini penerjemah hanya mengganti dialeknya saja, sehingga kata tersebut menjadi 'oke' dimana pengganti kata tersebut sudah lazim dan sering digunakan oleh pemakai bahasa sasaran.

Teknik terjemahan semantik merupakan jumlah terbanyak kedua dalam 'berjanji'. Contohnya: BSu: "Don't worry about it, Dad. It's not like that." (2:59); BSa: "Jangan khawatir soal itu, Dad, hubungan kami tidak seperti itu." (2:74). Secara semantik, tidak ada pergeseran secara gramatikal. Pada struktur tuturan pertama kalimat negatif tetap kedudukkannya sebagai kalimat negatif dalam BSa, demikian halnya dengan struktur tuturan kedua. 'It's' disini diterjemahkan menjadi 'hubungan kami', ditinjau dari konteks situasi yang terjadi, pilihan kata tersebut lazim. 'It's' sebagaimana diketahui bersama merupakan bentuk pronomina yang merujuk pada kata benda tertentu. Dalam konteks situasi tuturan ini, Bella merujuk pada pertanyaan ayahnya yang menanyakan tentang sejauh mana hubungan mereka, kekhawatiran seorang ayah terhadap anak gadisnya yang sedang jatuh cinta. Dalam BSa terjemahan ' $i t$ 's' yang demikian masih layak dan dapat diterima dan dengan baik.

Pembahasan tentang teknik terjemahan yang tak kalah pentingnya adalah teknik terjemahan bebas, dimana teknik ini lebih mengedepankan isi dan mengorbankan teks BSu-nya. Contohnya: BSu: "I'll make it up to you, you wash, I'll rinse and dry." (10:217); BSa: "Aku akan 'menebus' dosa-dosaku, kau mencuci, aku yang membilas dan mengeringkan." (10:241). Disini, frase 'make it up to you' diterjemahkan menjadi 'menebus dosa-dosaku'. Ditinjau dari makna harfiah frase tersebut berarti 'berusaha menyenangkan seseorang'. Hal ini dilakukan penerjemah kemungkinan meyesuaikan dengan situasi cerita yang ada dalam novel tersebut. Namun, menurut catatan rater, pemilihan frase $\mathrm{BSa}$ tersebut kurang akurat karena kurang sepadan dengan maksud konteks yang ada.

Untuk teknik terjemahan komunikasi dalam 'berjanji' ini, penerjemah cenderung menyampaikan isi yang disesuaikan dengan pembaca BSa. Misalnya saja dalam tuturan berikut: BSu: "I'll always be waiting in the wings, Bella," (26:602); BSa: "Aku akan selalu menunggu, Bella," (Meyer, 2010: 6:655). Pada tuturan tersebut, penerjemah mereduksi 'in the wings'. Dari catatan rater didapatkan, jika frase 'in the wings' turut serta diterjemahkan, maka hasil terjemahannya akan nampak kaku dan tidak luwes, karena frase tersebut secara harfiah berarti 'di samping-samping panggung' sementara kesepadanan atas makna harfiah tersebut tidak ada kesepadannya dalam BSa.

Secara keseluruhan tindak tutur komisif 'berjanji' tergolong akurat karena sebagian besar tindak 
tutur penelitian ini berada pada tataran mikro sehingga masih memungkinkan bila menggunakan teknik-teknik penerjemahan tersebut. Oleh karena itu, makna dari suatu tuturan pun masih dapat tersampaikan dengan baik. Sedangkan dalam hal keberterimaan, tindak tutur berjanji juga mempunyai presentase keberterimaan tinggi karena padanan katanya masih terasa wajar meskipun pada beberapa data dinilai kurang alamiah atau kurang wajar.

\section{SIMPULAN}

Tindak tutur komisif adalah tindak tutur yang mengikat penuturnya untuk melaksanakan segala hal yang disebutkan dalam ujarannya, misalnya bersumpah, berjanji, mengancam, menyatakan kesanggupan. Berdasarkan analisis terdapat 122 data bentuk tindak tutur komisif. Persentase terbesar ditemukan pada bentuk tindak tutur 'berjanji' (promise) yakni sebesar 52\% dengan jumlah 63 data, 'mengancam' (threaten) sebesar 17\% sebanyak 21 data, 'menyatakan kesanggupan' (volunteering) sebesar $13 \%$ atau 13 data, 'berniat (undertake) sebesar $11 \%$ atau 13 data, dan terendah adalah bentuk tindak tutur komisif 'bersumpah (vowing) sebesar $7 \%$ atau sebanyak 9 data temuan.

\section{DAFTAR PUSTAKA}

Meyer, S. (2010). The Twilight Saga Eclipse Gerhana (Alih Bahasa: Monica Dwi Chresnayani). Jakarta: PT. Gramedia Pustaka Utama.

Molina, L. and Albir, H.A. (2002). "Translation Techniques Revisited: A Dynamic and Functionalist Approach" dalam Meta: Journal des Traducteur/Meta: Translators' Journal. XLVII, No.4 hal. 498-512.

Winarno, S. (1995). Metode Penelitian. Bandung : Tarsito. 